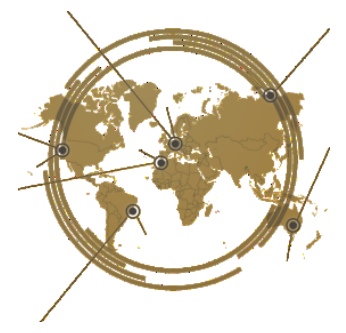

\title{
Investigating English needs of law department students in English for specific purposes
}

\author{
Ummu Artha Tsary Rumalessin ${ }^{1}$, Rafika Rabba Farah ${ }^{2 *}$ \\ ${ }^{1}$ Universitas Gadjah Mada, ${ }^{2}$ Universitas Muhammadiyah Malang
}

This present study aims at investigating the students' target needs in learning ESP Speaking of Law department students. The adapted version of Aliakbari \& Boghayeri's (2014) and Alsamadani's (2017) questionnaire was used as the main instrument of this study to understand the 45 students' perception about their needs in learning ESP speaking course. A mixed-method research design was implemented in this present research. Students' responses were analyzed statistically using SPSS 16.0 by calculating the mean, frequency and percentage. To elicit more understanding on the topic, interview was implemented to senior students in order to get deeper investigation about students' target needs. The interview data were then analyzed using NVivo 12 Plus. This study reveals that most of the students' needs are concerned with their professional job in the future so as they are able to use English in their fields. Thus, this study provides some highlighting points on what to include in course development. In such notion, this study suggests lecturers to provide specific materials related to law case in order to face their professional life either in short- or long-term future needs.

Keywords: Need analysis, law department, English for Specific Purpose, course development

\section{INTRODUCTION}

OPEN ACCESS ISSN 25033492 (online)

${ }^{*}$ Correspondence: Rafika Rabba Farah Irafikafarah@gmail.com

Received: 10th August 2020 Accepted: 18th November 2020

Published: 21th April 2021

Citation:

Rumalessin, U. A. T \& Farah, R. R. (2021). Investigating English needs

of law department students in English for specific purposes.

J. Eng. Educ. Society. 6:1. doi: 10.21070/jees.v6i1.1085
English for Specific Purposes (ESP) course is noteworthy to be considered as the course which designs the specific materials so as to meet learners' actual needs. According to Alsamadani (2017), ESP has been known as an approach in teaching and learning of English as a foreign and second language, this course is aims to enhance students' skills in understanding a particular domain. In addition, ESP is fundamental to be learned because it helps university students become more proficient in their field of study (Xhaferi \& Xhaferi, 2011). Besides, Salazar (2011) also states that ESP is a course which focuses on giving students specific skills necessary to carry out an activity related to a distinct professional task. Therefore, a need analysis study is compulsory to be conducted for ESP in order to investigate those important aspects before designing a material (Aliakbari \& Boghayeri, 2014).

Since such issue have been the growing interest for research topic in higher education and university level, numerous researchers have explored on this (Aliakbari \& Boghayeri, 2014); Chostelidou, 2011; Lee, 2016; Indrasari, 2016; Bosher \& Smalkoski, 2004; Xhaferi \& Xhaferi, 2011; Alsamadani, 2017). Most of them try out to go over the students' needs in terms of designing a right course over certain fields or majors. It is such a crucial point to ultimately investigate the effectiveness and efficiency of the existing course design through learners' needs. 
In addition, Pourshahian, Gholami, Vaseghi, \& Kalajahi (2012) state that needs analysis plays a vital asset for teacher to learn what aspects of language the learners need to study, what degree they need to study and why the learners study the language. If not been addressed, ESP teaching would bring a challenge on teacher's identity mainly from student and institutional aspect (Farah, 2018).

Moreover, it is also considered as the starting point of adopting a framework for ESP course design with the aim of highlighting all stakeholders' perception in the process of curriculum development, course and syllabus design, and evaluation of the effectiveness and efficiency of the implementation of the needs-based course (Chostelidou, 2011). Additionally, the more learner needs are clear, the more the objectives are expressed and the ESP course easily becomes successful (Albakrawi, 2013). In such notion, Xhaferi \& Xhaferi (2011) assert that using English in relevant studies will enable learners to learn the ways and situations they need to use the language in their perspective fields and help them to get ready to cope with everyday situations and deal with professional purposes, which could be an important concern in identification of the learners' needs. A mixture between English for Academic Purposes and General English is suggested for students in religious field (Farah \& Sumarsono, 2019). Moreover, Bosher \& Smalkoski (2004) highlights that the situational or function demands of the target setting were determined and curriculum design designed around "learners' lacks" or the gaps between the current skill of Law students and the target skill of Law students.

However, a number of research projects discussed previously are still fairly limited investigating about Law department students' area meanwhile their professional needs in particular about their oral skills are significant to be analyzed. Thus, this present research aims at investigating Law students' exact needs in ESP for speaking course with the formulated research question as follow: "What are the actual ESP Speaking needs of Law Department students?" In regards to this, the result of this research is significant for teacher or curriculum developer to use it as the needs of Law department students are clearly highlighted.

\section{METHODS \\ Research Design}

This present study used a mixed method design, encompassing a small scale of questionnaire and interviews. The questionnaires were distributed to the participants (students) to gain profound concepts into the English needs of Law department students. The participants were the first-semester students who are taking English for
Specific Purposes (ESP) course. Thus, the results of the questionnaire were further investigated by semi-structured interviews with three seniors students (seventh-semester students) who had taken English for Specific Purposes (ESP) in their first and second semester. The three participants were selected randomly based on their response in the questionnaire. The interviews presented as a triangulation of the findings from the questionnaire and provided deeper concepts of students needs as well.

\section{Research Instrument}

There were two kinds of instruments employed in this current study, namely (1) questionnaire and (2) interviews. The questionnaire was adapted from the study of Aliakbari \& Boghayeri (2014) and Alsamadani (2017) with some modifications to fit the context of the current research setting. This questionnaire was implemented as it has been tested in Cronbach's alpha consistency analysis to verify its reliability. Thus, the questionnaire was designed into 5-point Likert scale and devided into two parts that are intended to investigate the students' lacks and needs in learning ESP Speaking. There are 11 items in total. The questionnaire was distributed for firstsemester students who are currently taking an ESP Speaking course. The researchers came to their class and asking their permission to fill in the questionnaire in the class. During the process of filling out the questionnaire, the first-semester students were allowed to asked the researchers question orally related to the question that needed to be clarified.

The second instrument used was interviews. The interviews were conducted to senior students who have graduated or taken an ESP course. The interviews used semi-structured design and the interview guideline was developed based on the questionnaire results. The interview aimed at further investigating about whether or not the needs percieve by the first-semester students matched with their next related-courses in the next semester as well as their future job. Nevertheless, the interviewees might disagree or have different opinions of what need to be learned for ESP Speaking. Therefore, all the results were served as the findings in this study. In addition, all the interviews were fully recorded and transcribed.

\section{Research setting}

The study was carried out at Law Department of University Muhammadiyah Malang, focused on first-semester students with the total number of 45 students, consisting of 20 males and 25 females.

\section{Research Participants}

The participants for this present study were (1) first-semester students and (2) senior students at Law Department, Universitas 
Muhammadiyah Malang. The first participants filled the questionnaire. The number of the students was 45 in total.

The second participants were the seniour students who have finished or graduated from ESP program in their first year. Also, three-interview participants were recruited from senior students to verify their actual needs in real life used upon completing ESP course. The participants were to relate their needs based on the experience that they have been through while doing internship or from related-courses in their next semester.

\section{Data Analysis}

Since the two kinds of questionnaires (one questionnaire for investigating students' lacks and the others to explore students target needs) used 5-Likert scale, therefore the number of each item was calculated using Descriptive statistics which included calculating the mean, percentage and the frequency of each response to further analyze the data. Moreover, Statistical Package for Social Science (SPSS) 16.0 was used for the whole calculation. After analyzing the whole results, then, investigate the target needs by developing small syllabus based on the results and refer the results with relevant studies. Furthermore, the results of the interviews were transcribed and also coded to indicate the information about their thought of students' target needs of Law students using qualitative research analysis software, NVivo 12 Plus. Their overall interpretation was described qualitatively to support the results of the questionnaire.

\section{RESULTS AND DISCUSSION}

There were two sub-sections presented as the findings in this present study. The first one is the results of the questionnaire (quantitative analysis) while the second is the results of the interview (qualitative analysis).

\section{Analysis Data from First-semester Students}

The Law students' (first-semester students) perception of the English for Specific Purposes (ESP) Speaking needs were analyzed from the results of tabulating and analyzing each responses of the questionnaire. Descriptive Statictics which included the calculation of mean, percentages and frequencies were used and presented as the main source for analyzing the results.

Table 2. Descriptive Statistics of Perceived Students' Lacks of Speaking Skill

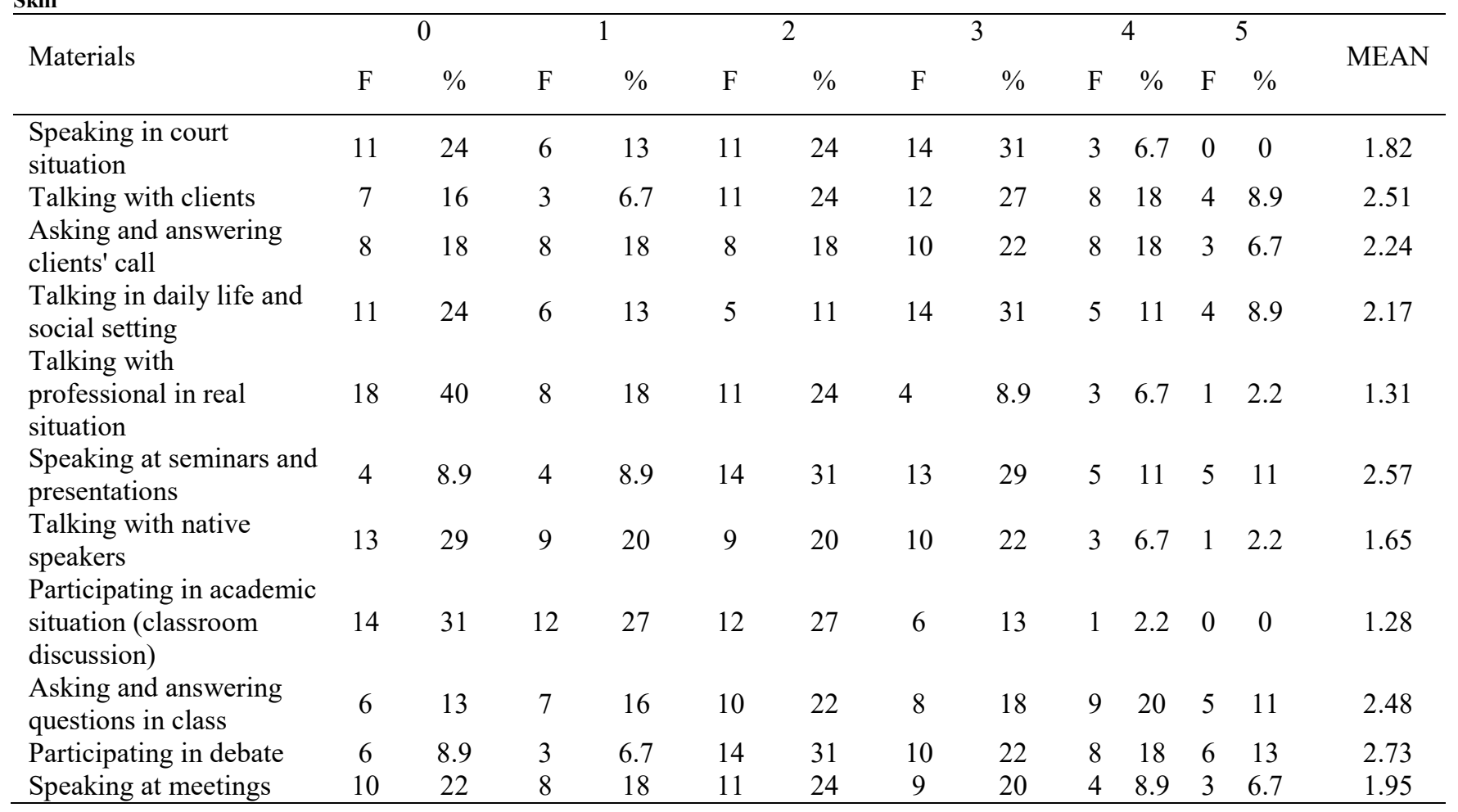

$\mathrm{F}=$ Frequency; $0=$ Very Poor; $1=$ Poor $; 2=$ Fair; $3=$ Good 4 = Very Good; $5=$ Excellent. 
From tabel 1, it can be learned that all of fourty five (45) students $(100 \%)$ replied that they have incapability skills almost for all the items in the questionnaire as indicated by the means ranging from 1.31 to 2.73 . This shows that they are still incapability in learning specific materials related to their majors.

Therefore, in table 2, they were perceived all the items in the questionnaire to be somehow very important to be learned and they definitely needed them very soon. This information as signified by the means from ranging 1.91 to 2.80 in the table. Nevertheless, in order to draw the students target need easily by the results of the means and percentage in the table $\underline{2}$, the items could be classified into two categories, that is strongly needed (as signified by mean of 2 and more than $50 \%$ of the participants with now and very soon responses), and less strongly needed (by means of 1 or below $50 \%$ of the participants with the next year up to no needed responses). The needs in the first category were speaking in court situation $(\overline{\mathrm{x}}=2.28)$, talking with clients $(\overline{\mathrm{x}}=2.08)$, asking and answering clients' calls $(\overline{\mathrm{x}}=2.37)$, talking in daily life and social setting $(\overline{\mathrm{x}}=2.22)$, talking with professional in real situation $(\overline{\mathrm{x}}=2.44)$, talking with native speakers $(\overline{\mathrm{x}}=2.60)$, Participating in academic situation (classroom discussion) $(\overline{\mathrm{x}}=2.80)$, asking and answering questions in class $(\overline{\mathrm{x}}=2.17)$, and speaking at meetings $(\overline{\mathrm{x}}=2.66)$.

Moreover, those belonged to the second category were speaking at seminars and presentations $(\overline{\mathrm{x}}=1.86)$ and participating in debate $(\overline{\mathrm{x}}=1.91)$.

Table 2. Descriptive Statistics of Perceived Target Needs of Speaking Skill

\begin{tabular}{|c|c|c|c|c|c|c|c|c|c|c|c|}
\hline \multirow{3}{*}{ MATERIALS } & \multicolumn{10}{|c|}{ RESPONSE } & \multirow{3}{*}{ MEAN } \\
\hline & \multicolumn{2}{|c|}{1} & \multicolumn{2}{|c|}{2} & \multicolumn{2}{|c|}{3} & \multicolumn{2}{|c|}{4} & \multicolumn{2}{|c|}{5} & \\
\hline & $\mathrm{F}$ & $\%$ & $\mathrm{~F}$ & $\%$ & $\mathrm{~F}$ & $\%$ & $\mathrm{~F}$ & $\%$ & $\mathrm{~F}$ & $\%$ & \\
\hline Speaking in court situation & 5 & 11.1 & 29 & 64.4 & 4 & 8.9 & 7 & 15.6 & 0 & 0 & 2.28 \\
\hline Talking with clients & 5 & 11.1 & 35 & 77.8 & 1 & 2.2 & 4 & 8.9 & 0 & 0 & 2.08 \\
\hline Asking and answering clients' call & 5 & 11.1 & 27 & 60 & 4 & 8.9 & 9 & 20 & 0 & 0 & 2.37 \\
\hline $\begin{array}{l}\text { Talking in daily life and social } \\
\text { setting }\end{array}$ & 9 & 20 & 25 & 55.6 & 3 & 6.7 & 8 & 17.8 & 0 & 0 & 2.22 \\
\hline $\begin{array}{l}\text { Talking with professional in real } \\
\text { situation }\end{array}$ & 5 & 11.1 & 25 & 55.6 & 5 & 11.1 & 10 & 22.2 & 0 & 0 & 2.44 \\
\hline $\begin{array}{l}\text { Speaking at seminars and } \\
\text { presentations }\end{array}$ & 14 & 31.1 & 26 & 57.8 & 2 & 4.4 & 3 & 6.7 & 0 & 0 & 1.86 \\
\hline Talking with native speakers & 3 & 6.7 & 23 & 51.1 & 8 & 17.8 & 11 & 24.4 & 0 & 0 & 2.6 \\
\hline $\begin{array}{l}\text { Participating in academic } \\
\text { situation (classroom discussion) }\end{array}$ & 23 & 51.1 & 8 & 17.8 & 14 & 31.1 & 0 & 0 & 0 & 0 & 2.8 \\
\hline $\begin{array}{l}\text { Asking and answering questions } \\
\text { in class }\end{array}$ & 7 & 15.6 & 30 & 66.7 & 2 & 4.4 & 5 & 11.1 & 1 & 2.2 & 2.17 \\
\hline Participating in debate & 10 & 22.2 & 32 & 71.1 & 3 & 6.7 & 0 & 0 & 0 & 0 & 1.91 \\
\hline Speaking at meetings & 4 & 8.9 & 22 & 48.9 & 5 & 11.1 & 13 & 28.9 & 1 & 2.2 & 2.66 \\
\hline
\end{tabular}

$\mathrm{F}=$ Frequency; $1=$ Now; 2 = Very Soon; $3=$ Next Year; $4=$ Don’t Know; $5=$ No

Needed

Table 3. Summary of the Perceived Needs in Two categories

\begin{tabular}{|c|c|c|}
\hline Skills & $\begin{array}{c}\text { Category } 1 \\
\text { (Strongly Needed) }\end{array}$ & $\begin{array}{c}\text { Category } 2 \\
\text { (Less Needed) }\end{array}$ \\
\hline Speaking & $\begin{array}{ll}\text { - } & \text { Speaking in court } \\
\text { situation } \\
\text { - } & \text { Asking and answering } \\
\text { clients' calls } \\
\text { - } \\
\text { Talking in daily life } \\
\text { and social setting } \\
\text { - } \quad \text { Talking with } \\
\text { professional in real } \\
\text { situation } \\
\text { - } \quad \text { Asking and answering } \\
\text { questions in class } \\
\text { - Speaking at meetings }\end{array}$ & $\begin{array}{ll}\text { - } & \text { Speaking at } \\
\text { seminars and } \\
\text { presentations } \\
\text { - } & \begin{array}{l}\text { Participating in } \\
\text { debate }\end{array}\end{array}$ \\
\hline
\end{tabular}

\section{The Results of the Interview}

In this section, the result of the interviews is transcribed then coded based on nodes created on NVivo 12 Plus software. The hierarchical chart and tree map emerged based on the coded transcription are shown as follows.

The nodes created for the analysis were long-term goal, short-term goal, and the needs on specific materials. The long-term objectives were accounted to have 19 coding references; short-term goal for 13 coding references; and the needs of specific materials for 9 coding references. 
It is found that the long-term goals are related to gaining competence to compete in international labor market, using English in court situation, solve client's problem, and understand legal knowledge.

The idea of Asian free trade area has required us to be able to speak English, mainly to understand western law or international case. (Participant A)

Our future clients are not always coming from local area, but can be international one. To deal with this, as future prosecutor, the ability of speaking English with client is necessary. (Participant B)

English is important for Law students, as someday when we apply for a job, we will meet the HRD staff during the interview. For me, having the ability to speak English can give us added value from the other applicants. (Participant C)

Short-term goal related to graduate from bachelor degree, having the courage to speak English in the classroom, to fulfill the assignment, read international journal.

English competence is necessary to complete our assignments as some courses like International Law, Law and Human Right, and Transnational Crime requires English as the language of instruction. (Participant A)

When I did my internship at Notary Public, I just realized that English is that important. There was a foreigner called us wanting to buy land, while no one could not speak English well, so the director called someone to help us. (Participant B).

Some of Law terminologies are difficult to understand. I once got confused understanding the term 'everyone must be equal before the law'. I thought that before here means 'the opposite meaning of after' in fact it is not. Also, the same thing happens when I tried to understand the continental, which later I know that this word means code. (Participant C)

It is very necessary to learn specific English because this matter around trial, client trust and satisfaction influences our reputation as legal expert and so that we better understand the problems experienced by clients even though we can also bring in translators. (Participant A)

We know that now is MEA era. So, we, as Law Department students need to learn more about English in our field, because mostly the terms in Law Department are using English. (Participant B)
As a lawyer or as a public prosecutor we have to dig out for information from the client, and our clients are not only from local but also foreigner. So, English in law department is crucial. (Participant C)

Therefore, the previously mentioned phenomena have led students into one conclusion that the needs of specific English materials are what the students have highlighted in this research. These needs have been clearly shown in the figure $\underline{1 .}$

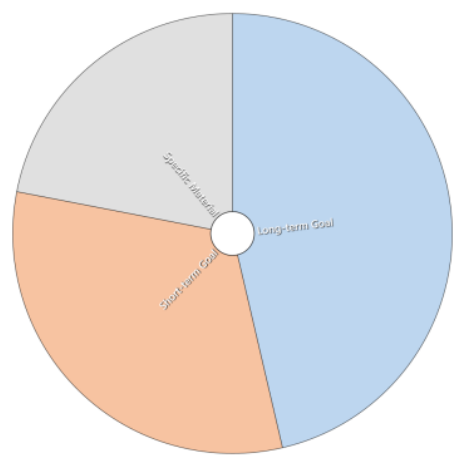

Figure 1. NVivo Hierarchy Chart of Interview Transcript

Based on the analysis, the 20 frequently mentioned words by the students are described in Figure 2. It is shown that the 20 frequent words emerge from the interview transcription among others are law, esp, speaking, English, court, course, judge, skills, defendants, communication, job, vocabulary, legal, client, situation, international, problem, assignment, debating, foreigner. From those words, it can be derived that provisioning Law students with ESP speaking can assist them to reach the short-term goal such as completing their lecture assignment in the form of international articles and to understand difficult vocabulary related to court situation; and to reach the long-term goal such as encouraging them to have better communication skills for future job such as to deal with client's problem and debating to judge's arguments, also to speak with foreigner. In addition, the hierarchy chart also highlights on students' expectation to learn specific materials.

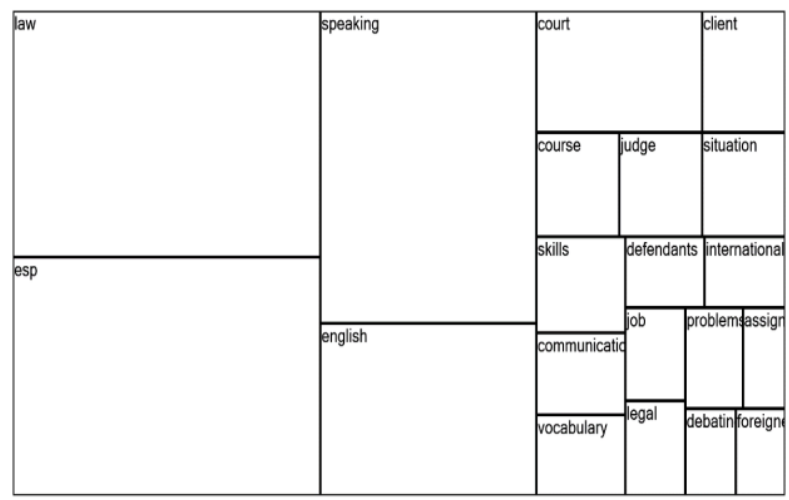

Figure 2. Tree Map of the Frequent Words 


\section{DISCUSSION}

This study on Law Department students showed list of needs in learning speaking and also justification from senior students. Eliciting from the results, the needs of Law students were focused on the professional needs in order to prepare the students cope with professional jobs. In regard with this, as suggested by some experts, English for Specific Purposes (ESP) seems to provide the actual materials to enhance the students' understanding about particular or specific domain to be more proficient in their field (Ahmed Alsamadani, 2017; Xhaferi \& Xhaferi, 2011; Xhaferi \& Xhaferi, 2011; and Salazar, 2011). Furthermore, it is also congruent with the findings of Liu, Chang, Yang, \& Sun (2011) that state students' attendance on ESP/AP course is to gain skills on their related jobs, or in another term Poedjiastutie \& Oliver, (2017) regard this as pragmatic use. In this current study, actual materials can be provided by the lecturers in teaching ESP Speaking course in their class for first-semester students. Hence, it can be assumed that ESP Speaking course is designed to stimulate the students' speaking skills in preparing them to cope with their professional challenges related to their future job. Moreover, as stated by the senior students, this course also will be useful for Law students in facing their study in the university about course-related challenges in the next years if the lecturers provide specific material. This information about the ESP materials provided is based on the work experience by senior students that strengthens the findings of this present study.

As suggested by Albakrawi (2013), the more learner needs are clear, the more the objectives are expressed and the ESP course easily becomes successful. Therefore by these results, the lecturers should consider students' needs prior to designing a syllabus for teaching. Not only from students' aspect, the clear needs will also helpful for ESP teachers to prepare their teaching, as a matter of fact, teaching ESP has been ambivalent experience for teachers (Ishak, 2019). In addition, ESP teachers has experienced what are so called as student-related challenge and institutional challenge (Farah, 2018). From the explanation and the results, it is interesting to design small syllabus for teaching ESP Speaking course for Law Department as listed in the columns of strongly-needed items.

\section{CONCLUSION}

Based on the results, this study has informed that most students of Law department needs' are concerned with their professional job in the future so as they are able to use English in their fields. Therefore, they expect the lecturers to provide specific materials related to Law case in order to face their professional life and cope with their academic challenge as well during the semester or even in upcoming semester. In other words, ESP in Law department has to be a course to facilitate the students' needs to learn English specifically so that both academic needs and professional needs can be implemented in one time.

The findings and discussion of this current study are expected to have contribution for all ESP practitioners in designing ESP course. Moreover, this present study is limited only for one particular skills which is ESP Speaking course. Therefore, further researcher are suggested to explore more on Law students' perception about another skills in learning ESP such as listening, reading, and writing.

\section{ACKNOWLEDGEMENT}

The researchers would like to convey their gratitude to Language Center Universitas Muhammadiyah Malang and all parties that have taken a part in accomplishing this research.

\section{REFERENCES}

Alsamadani, H.A. (2017). Needs analysis in esp context: saudi engineering students as a case study. Advances in Language and Literary Studies, 8(6), 58. https://doi.org/10.7575/aiac.alls.v.8n.6p.58

Albakrawi, H. T. M. (2013). Needs Analysis of the english language secondary hotel students in Jordan. International Journal of English Language Teaching, 1(1), 13-23.

Aliakbari, M., \& Boghayeri, M. (2014). A needs analysis approach to esp design in iranian context. Procedia Social and Behavioral Sciences, 98, 175-181. https://doi.org/10.1016/j.sbspro.2014.03.404

Bosher, S., \& Smalkoski, K. (2002). From need analysis to curriculum development: Designing a course in healthcare communication for immigrant students in USA. English for Specific Purposes, 21, 59-79.

Chostelidou, D. (2011). Needs-based course design: The impact of general English knowledge on the effectiveness of an ESP teaching intervention. Procedia - Social and Behavioral Sciences, 15, 403-409. https://doi.org/10.1016/j.sbspro.2011.03.112

Farah, R. R. (2018). Who am I? Interrogating My Identity as ESP Teacher: Personal Narration. CELTIC A Journal of Culture, English Language Teaching, Literature and Linguistics, 3(1), 1-15. https://doi.org/10.22219/CELTICUMM.Vol3.No1

Farah, R. R., \& Sumarsono, P. (2019). The English Needs of Islamic Studies Learners: ESP Speaking Course Model. Advances in Social Sciences, Education and Humanities Research, 349, 563-566. https://doi.org/.1037//0033-2909.I26.1.78

Indrasari, N. (2016). English for Specific Purposes: A Need Analysis at The Second Semester of Physics Education Students of IAIN Raden Intan Lampung in The Academic Year of 2015/2016. English Education: 
Jurnal Tadris Bahasa Inggris IAIN Raden Intan, 9(1), 161-172. https://doi.org/10.24042/ee-jtbi.v9i1.425

Ishak, C. N. (2019). Metaphorical Analysis of Teachers' and Students' Perception of ESP. 5(1), 56-76.

Lee, C.-L. (2016). Principles and Practices of ESP Course Design-A Case Study of. International Journal of Learning, Teaching and Educational Research, 15(2), 94-105.

Liu, J. Y., Chang, Y. J., Yang, F. Y., \& Sun, Y. C. (2011). Is what I need what I want? Reconceptualising college students' needs in English courses for general and specific/academic purposes. Journal of English for Academic Purposes, 10(4), 271-280. https://doi.org/10.1016/j.jeap.2011.09.002

Poedjiastutie, D., \& Oliver, R. (2017). Exploring Students' Learning Needs: Expectation and Challenges. English Language Teaching, 10(10), 124. https://doi.org/10.5539/elt.v10n10p124

Pourshahian, B., Gholami, R., Vaseghi, R., \& Kalajahi, S. A. R. (2012). Needs of an ESL context: A case study of iranian graduate students. World Applied Sciences Journal, 17(7), 870-873.

Salazar, A. S. (2011). Designing an EGBP Course : Needs analysis as a key determinant. Memorias de Las. Jornadas de Lenguas En Contacto, 133-142.

Xhaferi, B., \& Xhaferi, G. (2011). The English language skills in ESP for law course. LFE: Revista de Lenguas Para Fines Especificos, 1127(17), 431-448.

Conflict of Interest Statement: The authors declare that the research was conducted in the absence of any commercial or financial relationships that could be construed as a potential conflict of interest.

\begin{abstract}
Copyright (c) 2021 Ummu Artha Tsary Rumalessin, Rafika Rabba Farah. This is an open-access article distributed under the terms of the Creative Commons Attribution License (CC BY). The use, distribution or reproduction in other forums is permitted, provided the original author(s) and the copyright owner(s) are credited and that the original publication in thisjournal is cited, in accordance with accepted academic pratize. No use, distribution or reproduction is permitted which does not comply with these terms.
\end{abstract}

